Article - Agriculture, Agribusiness and Biotechnology

\title{
Influence of Oxygen Supply on Growth and Laccases Production by Pleurotus sajor-caju PS-2001 in Submerged Process
}

Fernanda Bettin ${ }^{1 *}$

https://orcid.org/0000-0002-3517-8277

Letícia Osório da Rosa ${ }^{1}$

https://orcid.org/0000-0002-1292-9197

\section{Queli Montanari ${ }^{1}$}

https://orcid.org/0000-0001-8408-4210
Simone Zaccaria ${ }^{1}$

https://orcid.org/0000-0001-9259-6064

\author{
Aldo José Pinheiro Dillon' \\ https://orcid.org/0000-0002-1969-1740 \\ Mauricio Moura da Silveira ${ }^{1}$ \\ https://orcid.org/0000-0003-3408-2238
}

${ }^{1}$ University of Caxias do Sul, Institute of Biotechnology, Caxias do Sul, Rio Grande do Sul, Brazil.

Received: 2019.01.10; Accepted: 2020.02.13.

*Correspondence: fbettin@ucs.br; Tel.: +55-54-3218-2669 (F.B.)

\section{HIGHLIGHTS}

- Dissolved oxygen (DO) concentration affects fungal growth and laccases activity.

- Synthesis of laccases is favoured when DO is controlled at $30 \%$ of saturation.

- Medium pH at 6.5 , with DO at $30 \%$, reduces growth but increases enzymatic activity.

- Under these best conditions, laccases activity of $80 \mathrm{U} \mathrm{mL}^{-1}$ is attained after $66 \mathrm{~h}$.

Abstract: (1) Background: Oxygen supply is an important parameter to be considered in submerged cultures. This study evaluated the influence of different conditions for dissolved oxygen (DO) concentration on laccases activities and growth of Pleurotus sajor-caju PS-2001 in submerged process in stirred-tank bioreactor. (2) Methods: Initially, three different conditions were tested: uncontrolled DO and minimum levels of $30 \%$ and $80 \%$ of saturation, with the $\mathrm{pH}$ controlled between 4.5 and 7.0 . (3) Results: Best results were observed at $30 \% \mathrm{DO}\left(26 \mathrm{U} \mathrm{mL}^{-1}\right.$ of laccases at $96 \mathrm{~h}$ ), whereas higher mycelial biomass was observed at $30 \%$ and $80 \%$ DO (above $4.5 \mathrm{~g} \mathrm{~L}^{-1}$ ). Four different conditions of DO (uncontrolled, $10 \%, 30 \%$ and $50 \%$ of saturation) were tested at $\mathrm{pH} 6.5$, with higher laccases activity $\left(80 \mathrm{U} \mathrm{mL}^{-1}\right.$ at $\left.66 \mathrm{~h}\right)$ and lower mycelial growth $\left(1.36 \mathrm{~g} \mathrm{~L}^{-1}\right.$ at $\left.90 \mathrm{~h}\right)$ being achieved with DO of $30 \%$. In this test, the highest values for volumetric productivity and specific yield factor were determined. Under the different $\mathrm{pH}$ conditions tested, the production of laccases is favoured at DO concentration of $30 \%$ of saturation, while superior DO levels favours fungal growth. (4) Conclusion: The results indicate that dissolved oxygen concentration is a critical factor for the culture of $P$. sajor-caju PS-2001 and has important effects not only on laccases production but also on fungal growth.

Keywords: Pleurotus sajor-caju; submerged process; stirred-tank bioreactor; phenol-oxidases; laccases; dissolved oxygen concentration.

\section{INTRODUCTION}

The genus Pleurotus is a cosmopolitan group of mushrooms of high nutritional value, with therapeutic and medicinal properties. Besides their gastronomical value, these mushrooms produce molecules with 
interesting biological activities, with emphasis on ligninolytic enzymes, which have a wide range of environmental and biotechnological applications [1,2]. The major phenol-oxidases enzymes include manganese peroxidases (MnP - E.C. 1.11.1.13), lignin peroxidases (LiP - E.C. 1.11.1.14), and laccases (Lac - E.C. 1.10.3.2), secreted in the extracellular growth medium of ligninolytic fungi $[3,4]$, and they are produced in response to low levels of carbon and nitrogen sources [5]. Their non-specific oxidative mechanism in relation to the substrate enable degrading a variety of pollutants to carbon dioxide and water, allowing enzyme-producing microorganisms to degrade compounds structurally similar to those derived from lignin [6].

Laccases were discovered in exudates of the Japanese lacquer tree (Rhus vernicifera), and it was later found out that the lacquer was actually produced by fungi [7]. They are multicopper enzymes that catalyze the oxidation of several inorganic substances and aromatic compounds, particularly phenols, with the concurrent reduction of oxygen to water [8]. The catalytic properties of fungal laccases contribute to an efficient degradation of xenobiotic compounds, wastewater remediation and degradation of pharmaceuticals products [9-11]. Laccases-mediated systems are a promising alternative in biotechnological processes of environmental interest, e.g. pulp bleaching, discoloration of textile dyes, oxidation of polycyclic aromatic hydrocarbons, detoxification of endocrine-disrupting chemical effluents and environmental pollutants, and phenol removal [12-16]. In addition, they might be used in industries such as cosmetics, chemicals, pharmaceutics, foods and beverages, as well as for preparing clinical diagnostics, biosensors, clarifying and stabilizing fruit juices, and improving the quality of animal feed [17-20].

The process of controlling solid-state cultures is sometimes difficult due to the relatively long time for enzyme production, frequent contaminations during substrate handling, and poor oxygen transfer. Compared to solid state cultures, submerged processes represent an alternative and fast method that allow producing a higher biomass volume in less time, favouring fungal dispersion and adaptation [21,22]. By varying culture conditions, a higher yield can be obtained, as growth in submerged process is a rapid method for obtaining mycelial biomass and enzymes production [23,24]. Submerged process gives rise to potential advantages of higher mycelial production in a compact space and shorter time with lesser chances of contamination [25]. For several Pleurotus strains, adaptation to varying growth conditions in submerged cultures is relatively rapid [26]. Pleurotus sajor-caju PS-2001 shows optimal growth in liquid culture [24]. It is also an important laccases producer [27-29].

Besides the control of culture conditions such as inoculum concentration, $\mathrm{pH}$, temperature, and medium composition, with the aim of increasing productivity and preventing limitation of substrate and other nutrients, oxygen supply is an important parameter to be considered in submerged cultures. Adequate oxygen supply to the fungus is related to several aspects as morphology of the producing organism, system agitation status, air flow, and bioreactor setup [22,30], and affects cellular growth, enzyme production, culture medium rheology, and biosynthesis of metabolites and products [22,31,32].

Culture conditions that promote pellet formation are particularly demanding in terms of oxygen transfer because biomass greatly influences the rheological properties of the medium. Nevertheless, it should be stressed that oxygen transfer, specifically during pellet formation, is a complex function that is linked to operational parameters such as stirring, volumetric ratio and reactor size [33]. Stirred-tank reactors (STR) have great operational flexibility; however, this type of reactor requires the application of great power to keep the homogeneity of the system and supply oxygen to the microbial population. Under this condition, the agitation impellers promote a relevant difference between the velocities of liquid and solid phases, the last one represented by the fungal biomass, that could cause shear stress and partial destruction of mycelium $[16,28]$. Thus, the present study evaluated the effect of oxygen supply on laccases production and growth of $P$. sajor-caju PS-2001 in submerged culture in a laboratory-scale stirred-tank bioreactor.

\section{MATERIAL AND METHODS}

\section{Organism, media, and culture conditions}

The present study used Pleurotus sajor-caju strain PS-2001 obtained from the culture collection of the Institute of Biotechnology of the University of Caxias do Sul (Caxias do Sul, Brazil). The strain was grown and maintained in medium containing (per liter): Pinus spp. sawdust, $20 \mathrm{~g}$; wheat bran, $20 \mathrm{~g}$; $\mathrm{CaCO}_{3}, 2 \mathrm{~g}$; agar-agar, $20 \mathrm{~g}$ [27].

The culture medium for inocula preparation and bioreactor experiments contained (per liter): glucose, 5 g; pure casein, $1.5 \mathrm{~g}$; $\mathrm{CuSO}_{4}, 100 \mathrm{mg}$; benzoic acid, $100 \mathrm{mg}$; mineral solution, $100 \mathrm{~mL}$ [29]. The mineral

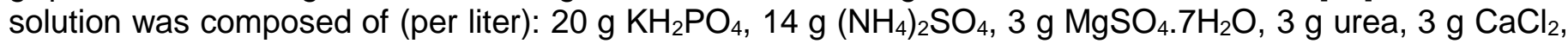
$15.6 \mathrm{~g} \mathrm{MnSO}_{4} . \mathrm{H}_{2} \mathrm{O}, 50 \mathrm{mg} \mathrm{FeSO}_{4}, 14 \mathrm{mg} \mathrm{ZnSO}_{4}$, and $20 \mathrm{mg} \mathrm{CoCl}_{2}$. The medium was autoclaved at 1 atm 
for 15 minutes prior to inoculation [27]. To start inoculum cultivation, three mycelial disks ( $1.5 \mathrm{~cm}$ diameter), each scraped from Petri dishes containing the fungal strain grown on maintenance medium, were added to $500-\mathrm{mL}$ Erlenmeyer flasks containing $100 \mathrm{~mL}$ of medium. Growth occurred for 6 days under reciprocal agitation of $180 \mathrm{rpm}$ at $28 \pm 2^{\circ} \mathrm{C}$. For each treatment, $10 \%(\mathrm{v} / \mathrm{v})$ of inoculum were used [28].

Experiments in the bioreactor were performed in a B. Braun Biotech device model Biostat ${ }^{\circledR} \mathrm{B}$ in batch mode. The initial impeller speed was $200 \mathrm{rpm}$ and the air flow rate was $2 \mathrm{~L} \mathrm{~min}^{-1}$ [28]. Under these conditions, the volumetric oxygen transfer coefficient $\left(\mathrm{K}_{\mathrm{L} a}\right)$ before inoculation was $12 \mathrm{~h}^{-1}$, calculated according to the method described by Sobotka and coauthors [34] in cell-free medium. Following inoculation, dissolved oxygen (DO) concentration in the medium was at $100 \%$ of saturation, with decreasing values being observed during the process due to the metabolic activity of the microorganism.

In tests conducted under automatically controlled $\mathrm{pH}$ in the range between 4.5 and 7.0, three culture conditions were assessed in relation to oxygen supply. In the first condition, air flow rate and impeller speed did not change during the process and, therefore, DO content in relation to saturation decreased to $0 \%$ of saturation (uncontrolled), whereas DO concentrations in the remaining two conditions were maintained between 30 and $80 \%$ of saturation by automatic air flow rate variation.

In tests conducted at fixed $\mathrm{pH}$ of 6.5 [14], four cultivation conditions were evaluated with respect to the oxygen supply: uncontrolled DO and maintenance at minimum levels of 10,30 and $50 \%$ of saturation.

In all tests, the $\mathrm{pH}$ was automatically controlled by adding $2 \mathrm{~mol} \mathrm{~L}^{-1} \mathrm{NH}_{4} \mathrm{OH}$ or $2 \mathrm{~mol} \mathrm{~L}^{-1} \mathrm{H}_{2} \mathrm{SO}_{4}$. Silicone antifoam agent was added to the medium before inoculation, at a ratio of $0.1 \mathrm{~mL} \mathrm{~L}^{-1}$, as defined by Bettin and coauthors [27]. The cultivation medium volume in the bioreactor was $4 \mathrm{~L}$ [28]. The system was kept at a controlled temperature of $28 \pm 1^{\circ} \mathrm{C}$, and the studied variables were monitored for $168 \mathrm{~h}$ in the tests with $\mathrm{pH}$ between 4.5 and 7.0, and for $90 \mathrm{~h}$ when the $\mathrm{pH}$ was controlled at 6.5.

\section{Sampling procedure and determination of fungal biomass}

For each experiment, samples were collected, centrifuged at $3000 \mathrm{~g}$ for 15 minutes at $25^{\circ} \mathrm{C}$, and the supernatant was used in the analytical procedures. All determinations were done in triplicate.

Mycelial biomass was determined gravimetrically after drying at $90^{\circ} \mathrm{C}$ for $24 \mathrm{~h} \mathrm{[28].}$

\section{Enzyme assays}

Laccases (Lac) activity was determined at $25^{\circ} \mathrm{C}$ by using $0.45 \mathrm{mmol}^{-1}$ 2,2'-azinobis-3ethylbenzothiazoline-6-sulfonic acid (ABTS - Sigma ${ }^{\circledR}$ ) as substrate in reaction mixtures containing $90 \mathrm{mmol}$ $\mathrm{L}^{-1}$ sodium acetate buffer ( $\left.\mathrm{pH} 5.0\right)$ and an appropriate amount of culture supernatant. ABTS oxidation was estimated by measuring the increase in absorbance at $420 \mathrm{~nm}\left(\varepsilon_{420}=3.6 \times 10^{4} \mathrm{~cm}^{-1} \mathrm{~mol}^{-1}\right)$ for 90 seconds [35]. Total peroxidase (Per) activity was estimated in a procedure similar to that of laccases determination in a reaction medium containing ABTS as substrate and $200 \mu \mathrm{mol} \mathrm{L}^{-1} \mathrm{H}_{2} \mathrm{O}_{2}$, as described by Heinzkill and coauthors [36].

Manganese peroxidase (MnP) activity was assayed at $30^{\circ} \mathrm{C}$ using $50 \mu \mathrm{g} \mathrm{mL}^{-1}$ phenol red (Merck ${ }^{\circledR}$ ) as substrate, $50 \mu \mathrm{mol} \mathrm{L}^{-1} \mathrm{MnSO}_{4} \cdot \mathrm{H}_{2} \mathrm{O}, 50 \mu \mathrm{mol} \mathrm{L}^{-1} \mathrm{H}_{2} \mathrm{O}_{2}, 12.5 \mathrm{mmol} \mathrm{L}^{-1}$ sodium lactate, $500 \mu \mathrm{g} \mathrm{mL}^{-1}$ bovine

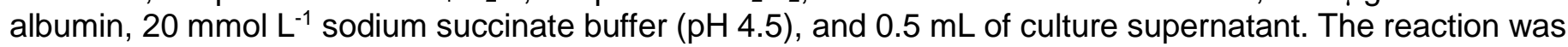
stopped by adding $40 \mu \mathrm{L}$ of $2 \mathrm{~mol} \mathrm{~L}^{-1} \mathrm{NaOH}$ to the mixture. The oxidation of phenol red was determined by measuring the increase in absorbance at $610 \mathrm{~nm}\left(\varepsilon_{610}=4.46 \times 10^{4} \mathrm{~mol}^{-1} \mathrm{~cm}^{-1}\right)$ [37]. For Lac and $\mathrm{MnP}$, one unit of enzyme activity was defined as the amount that catalyzes the production of $1 \mu \mathrm{mol}$ of colored product per $\mathrm{mL}$ of sample per min.

Veratryl alcohol oxidase (VAO) activity was assayed by measuring the increase in absorbance at 310 $\mathrm{nm}\left(\varepsilon_{310}=9.3 \times 10^{3} \mathrm{~mol}^{-1} \mathrm{~cm}^{-1}\right)$ in the presence of veratryl alcohol $\left(\right.$ Sigma $\left.{ }^{\circledR}\right)$ in $250 \mathrm{mmol} \mathrm{L}^{-1}$ sodium tartrate buffer ( $\mathrm{pH} \mathrm{5.0)}$ for $5 \mathrm{~min}$ [38]. Lignin peroxidase (LiP) activity was assayed as previously described using veratryl alcohol and $\mathrm{H}_{2} \mathrm{O}_{2}$ as substrate in $250 \mathrm{mmol} \mathrm{L}^{-1}$ sodium tartrate buffer $(\mathrm{pH} 3.0)$ for $5 \mathrm{~min}\left(\varepsilon_{310}=9.3 \mathrm{x}\right.$ $10^{3} \mathrm{~mol}^{-1} \mathrm{~cm}^{-1}$ ) [39]. For VAO and LiP, one enzyme unit corresponds to the amount of enzyme that oxidizes $1 \mu \mathrm{mol}$ of veratryl alcohol per $\mathrm{mL}$ of sample per min.

Proteases were determined using azocasein as substrate in $50 \mathrm{mmol} \mathrm{L}^{-1}$ sodium phosphate buffer $(\mathrm{pH}$ 7.0). Reactions were conducted at $40^{\circ} \mathrm{C}$ for $40 \mathrm{~min}$ and were stopped by adding $10 \%(\mathrm{~m} / \mathrm{v})$ trichloroacetic acid (TCA). Samples then rested for $15 \mathrm{~min}$ for complete precipitation of bigger fragments of azocasein, centrifuged at $10000 \mathrm{rpm}$ for $5 \mathrm{~min}$, and then $1 \mathrm{~mol} \mathrm{~L}^{-1}$ sodium hydroxide was added. Absorbance was measured spectrophotometrically at $440 \mathrm{~nm}$, according to Sarath and coauthors [40]. One enzymatic unit was defined as the amount of enzyme required for producing in a 1-cm cuvette a variation in absorbance of one unit. 


\section{Determination of substrate and soluble proteins concentrations}

Substrate concentration was quantified by the DNS (3,5-dinitrosalicilic acid - Sigma ${ }^{\circledR}$ ) method proposed by Miller [41] using glucose as standard. Protein concentrations were determined by the method of Bradford [42] using bovine serum albumin as standard.

\section{Measurement of dissolved oxygen concentration}

Dissolved oxygen concentration (DO) was measured using a sterilizable polarographic electrode coupled to the bioreactor. The electrode was calibrated previously to inoculation by bubbling air and nitrogen in the cultivation medium in order to set respectively the values for 100 and $0 \%$ of the saturation in oxygen in the liquid phase.

\section{Yield factors, productivities and specific activity}

Laccases activity yield from glucose $\left(Y_{E / S}\right)$, in $\mathrm{U} \mathrm{g}^{-1}$, was calculated by the relationship $Y_{\mathrm{E} / \mathrm{S}}=\left[\left(E_{\mathrm{f}}-E_{\mathrm{i}}\right)\right.$. $1000] /\left(S_{\mathrm{i}}-S_{\mathrm{f}}\right)$, where $E_{\mathrm{f}}$ is the final enzymatic activity in $U \mathrm{~mL}^{-1}, E_{\mathrm{i}}$ is the initial enzymatic activity in $\mathrm{U} \mathrm{mL}^{-1}$, $S_{i}$ is the initial substrate concentration in $\mathrm{g} \mathrm{L}^{-1}$, and $S_{\mathrm{f}}$ is the final substrate concentration in $\mathrm{g} \mathrm{L}^{-1}$.

Biomass yield from glucose $\left(Y_{X / S}\right)$, in $\mathrm{g} \mathrm{g}^{-1}$, was calculated by the relationship $Y_{X / S}=\left(X_{\mathrm{f}}-X_{\mathrm{i}}\right) /\left(S_{\mathrm{i}}-S_{\mathrm{f}}\right)$, where $X_{\mathrm{f}}$ is the final biomass concentration in $\mathrm{g} \mathrm{L}^{-1}, X_{\mathrm{i}}$ is the initial biomass concentration in $\mathrm{g} \mathrm{L}^{-1}, S_{\mathrm{i}}$ is the initial substrate concentration in $\mathrm{g} \mathrm{L}^{-1}$, and $S_{\mathrm{f}}$ is the final substrate concentration in $\mathrm{g} \mathrm{L}^{-1}$.

Specific yield factor $\left(Y_{E / X}\right)$, in U.g-1, was calculated by the relationship $Y_{E / X}=\left(E_{\max }\right) /\left(X_{\max }\right)$, where $E_{\max }$ represents the maximum laccases activity in $\mathrm{U} \mathrm{mL}^{-1}$ and $X_{\max }$ the maximum biomass concentration in $\mathrm{g} \mathrm{L}^{-1}$.

Enzymatic productivity $\left(P_{\mathrm{E}}\right)$, in $\mathrm{U} \mathrm{mL}^{-1} \mathrm{~h}^{-1}$, was calculated by the relationship $P_{\mathrm{E}}=\left(E_{\mathrm{f}}-E_{\mathrm{i}}\right) / t$, where $E_{\mathrm{f}}$ is the final enzymatic activity in $\mathrm{U} \mathrm{mL}^{-1}, E_{\mathrm{i}}$ is the initial enzymatic activity in $\mathrm{U} \mathrm{mL}^{-1}$, and $t$ is the time of cultivation in hours.

Biomass productivity $\left(P_{\mathrm{X}}\right)$, in $\mathrm{g} \mathrm{L}^{-1} \mathrm{~h}^{-1}$, was calculated by the relationship $P_{\mathrm{X}}=\left(X_{\mathrm{f}}-X_{\mathrm{i}}\right) / t$, where $X_{\mathrm{f}}$ is the final cellular concentration in $\mathrm{g} \mathrm{L}^{-1}, X_{\mathrm{i}}$ is the initial cellular concentration in $\mathrm{g} \mathrm{L}^{-1}$, and $t$ is the time of cultivation in hours.

The specific activity of laccases in relation to protein concentration ( $\left.S A_{\text {Lac }}\right)$, in $U \mathrm{mg}^{-1}$, was calculated by the relationship $S A_{\mathrm{Lac}}=\left(E_{\max } \times 1000\right) /[T S P]$, where $E_{\max }$ is (maximum laccases activity $\left.-\mathrm{U} \mathrm{mL}^{-1}\right) ;[T S P]$ (total soluble protein concentration $-\mathrm{mg} \mathrm{L}^{-1}$ ). In addition, the specific activity of laccases in relation to biomass concentration ( $S A_{\text {Lac }}$ ), in $\mathrm{U} \mathrm{g}^{-1}$, was calculated by $S A_{\mathrm{Lac}}=\left(E_{\max } \times 1000\right) /[X]$, where $E_{\max }$ (maximum laccases activity $\left.-U \mathrm{~mL}^{-1}\right) ;[X]$ (biomass concentration $-\mathrm{g} \mathrm{L}^{-1}$ ).

\section{RESULTS}

\section{Bioreactor cultivations at $\mathrm{pH}$ controlled between 4.5 and 7.0}

During the experiments, three different conditions of oxygen concentration (DO) were tested (uncontrolled, $30 \%$ and $80 \%$ of saturation in the medium), using basic medium constituted of glucose, pure casein and mineral solution added of $\mathrm{CuSO}_{4}$ and benzoic acid as enzymatic inducers at $\mathrm{pH}$ controlled between 4.5 and $7.0[28,29]$.

Figure 1 shows laccases activities, substrate and biomass concentrations during the 168 hours of the experiment. Amongst the conditions tested, optimal results were obtained using a $30 \%$ DO concentration in culture medium, with higher laccases activity of approximately $26 \mathrm{U} \mathrm{mL}^{-1}$ at $96 \mathrm{~h}$ of cultivation (Figure 1B). The condition of uncontrolled DO saturation showed intermediate levels of laccases activity, with maximum titles of $18 \mathrm{U} \mathrm{mL}^{-1}$ also at $96 \mathrm{~h}$ of cultivation (Figure 1A). However, the experiment performed at $80 \%$ saturation showed lower enzymatic titles than the other experiments $\mathrm{s}$, with higher laccases activity of $7 \mathrm{U} \mathrm{mL}^{-}$ 1 at $24 \mathrm{~h}$, and subsequent decrease until the end of cultivation (Figure 1C), indicating that this high DO concentration does not favour enzyme production.

With respect to the substrate and biomass concentration data, in all conditions assayed, only residual levels of glucose were observed at $72 \mathrm{~h}$ of cultivation (Figure 1), evidencing that variations in oxygen concentration did not interfere in substrate consumption. At the beginning of cultivation, fungal biomass data (Figure 1) showed similar kinetics in all conditions assayed; however, maximum biomass during the uncontrolled condition (approximately $2.5 \mathrm{~g} \mathrm{~L}^{-1}$ at $72 \mathrm{~h}$ of cultivation) was lower than values obtained in the other experiments (Figure 1A), which might be due to inadequate oxygen supply during the growth and substrate consumption phase. At 30 and $80 \% \mathrm{O}_{2}$ concentrations (Figure $1 \mathrm{~B}$ and $1 \mathrm{C}$ ), biomass values - both higher than $4.5 \mathrm{~g} \mathrm{~L}^{-1}$ - were reached at 72 and $90 \mathrm{~h}$ of cultivation, respectively.

Substrate consumption, completed at $72 \mathrm{~h}$, was similar in the various conditions assayed, which might 
have contributed to a possible biomass lysis after $96 \mathrm{~h}$ of cultivation (Figure 1), whereas there was a decrease in the biomass levels after detecting the maxima. During the experiment at $80 \%$ of saturation, the variation of the air flow rate up to a maximum of $10 \mathrm{~L} \mathrm{~min}^{-1}$ was not enough to keep DO concentration at the desired level. In fact, DO decreased sharply at $48 \mathrm{~h}$ of cultivation to approximately $50 \%$. It is important to remark that the option of controlling oxygen concentration by increasing impellers speed was not used in order to avoid mycelial shearing. During the $30 \%$ experiment, concentration decreased naturally to the specified level and remained unchanged until the end of the experiment (data not shown). During the uncontrolled-DO experiment, null concentrations were detected only between 48 and $72 \mathrm{~h}$, because initial culture conditions (200 rpm, $0.5 \mathrm{vvm}$ ) were not altered. At the end of the experiment (after $120 \mathrm{~h}$ ), levels were restored to approximately $100 \%$. The $\mathrm{pH}$ values, which were maintained between 4.5 and 7.0 , were measured along the experiment and it was observed that the lowest $\mathrm{pH}$ that occurred after $24 \mathrm{~h}$ of process coincided with the lowest DO. During the cultivation, this phase showed the more intense metabolic activity; after that (from 72 $\mathrm{h}$ onwards), data from all conditions assayed showed a $\mathrm{pH}$ increase within the controlled levels (data not shown).
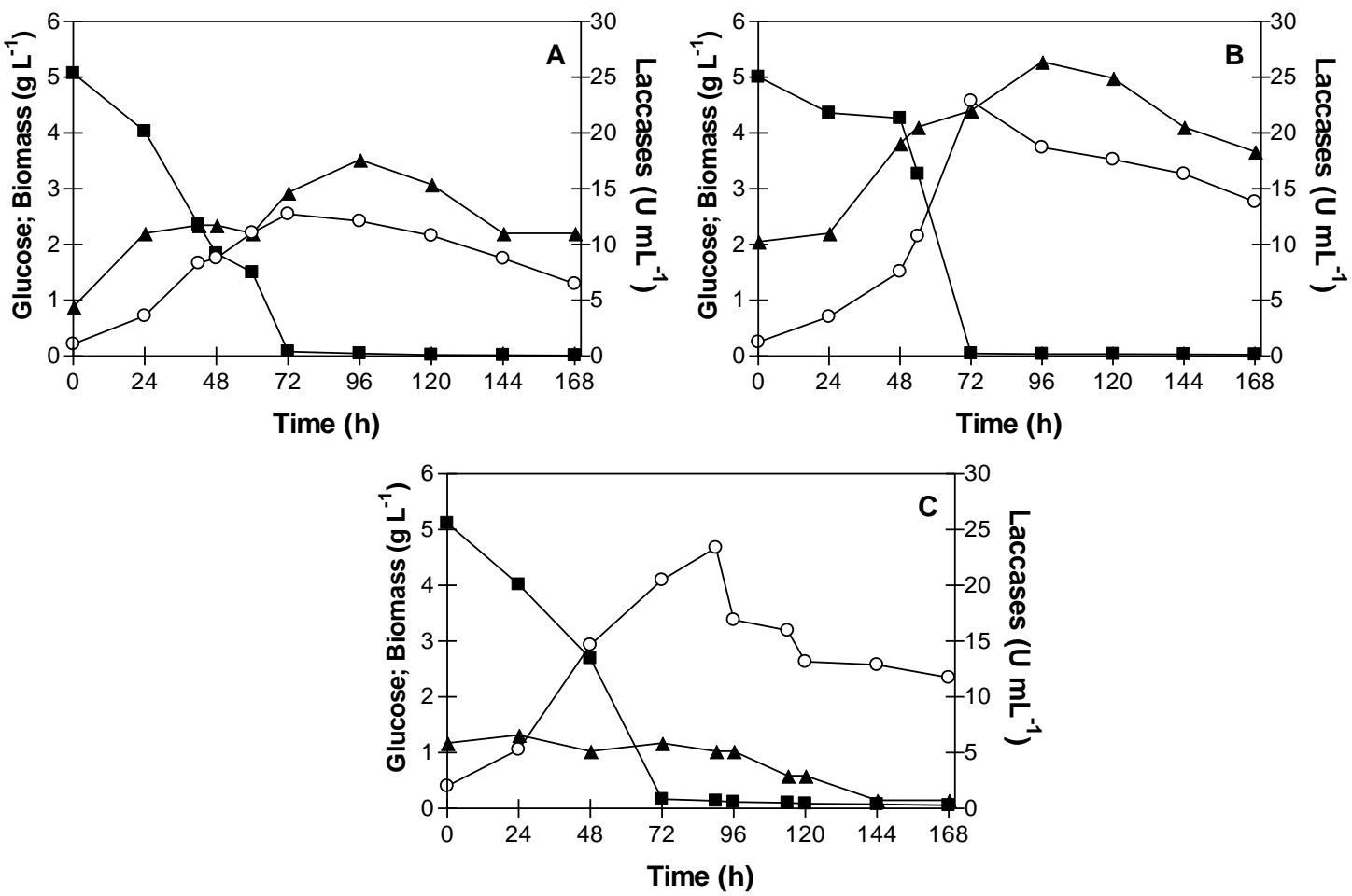

Figure 1. Laccases activity $(\boldsymbol{\Delta})$ and glucose $(\boldsymbol{\Xi})$ and biomass $(0)$ concentrations during submerged cultivations of Pleurotus sajor-caju PS-2001 in stirred-tank bioreactor under different conditions for dissolved oxygen concentration, at $\mathrm{pH}$ controlled between 4.5 and 7.0. Uncontrolled oxygen concentration (A), 30\% (B) and $80 \%$ of saturation (C).

The maximum activities of phenol-oxidases and proteases quantified in the cultures are presented in Table 1. Total peroxidases were detected in all experiments, with highest levels at $30 \% \mathrm{DO}$, as observed for laccases (Figure 1B); at $80 \%$ saturation, titles were lower than $1 \mathrm{U} \mathrm{mL}^{-1}$, with intermediate levels being attained with uncontrolled DO concentrations. For MnP, highest titles were obtained at $80 \%$ DO concentration. LiP and VAO activities were less than $1 \mathrm{U} \mathrm{mL}^{-1}$ in all conditions tested. For proteases, the highest activities $\left(7-10 \mathrm{U} \mathrm{mL}^{-1}\right)$ were detected at $80 \%$ concentration right from the beginning of cultivation on, which might be related to the lower laccases activity observed during this experiment (Figure 1), together with greater mycelial damage due to high specific air flow $\left(10 \mathrm{~L} \mathrm{~min}^{-1}\right)$; in the other experiments, proteolytic activity was similar in all times evaluated, showing a small increase at the end of cultivations (maximum of 3 $\left.\mathrm{U} \mathrm{mL}^{-1}\right)$. 
Table 1. Maximum activities of phenol-oxidases and proteases observed during submerged cultivations of Pleurotus sajor-caju PS-2001 in stirred-tank bioreactor under different conditions for dissolved oxygen concentration at $\mathrm{pH}$ controlled between 4.5 and 7.0.

\begin{tabular}{|c|c|c|c|}
\hline \multirow{2}{*}{ Enzyme activity } & \multicolumn{3}{|c|}{ Dissolved oxygen (per cent minimum of saturation) } \\
\hline & Uncontrolled & $30 \%$ & $80 \%$ \\
\hline $\mathrm{Lac}_{\max }\left(\mathbf{U} \mathrm{mL}^{-1}\right)$ & 17.6 & 26.4 & 6.6 \\
\hline$t_{\text {Lac,max }}(h)$ & 96 & 96 & 24 \\
\hline $\operatorname{Per}_{\max }\left(\mathrm{U}^{\mathrm{mL}} \mathrm{L}^{-1}\right)$ & 2.9 & 3.7 & 0.7 \\
\hline$t_{\text {Per,max }}(h)$ & 120 & 168 & 24 \\
\hline $\mathrm{MnP}_{\max }\left(\mathrm{U} \mathrm{mL}^{-1}\right)$ & 2.9 & 3.4 & 6.5 \\
\hline$t_{M n P, \max }(h)$ & 42 & 168 & 168 \\
\hline $\mathrm{LiP}_{\max }\left(\mathbf{U} \mathrm{mL}^{-1}\right)$ & 0.7 & 0.4 & 0.1 \\
\hline$t_{L i P, \max }(h)$ & 96 & 120 & 144 \\
\hline $\mathrm{VAO}_{\max }\left(\mathrm{U} \mathrm{mL}^{-1}\right)$ & 0.2 & 0.3 & ND \\
\hline$t_{V A O, \max }(h)$ & 48 & 120 & --- \\
\hline Proteases & 3.1 & 3.4 & 10.3 \\
\hline$t_{\text {Prot,max }}(h)$ & 144 & 144 & 120 \\
\hline
\end{tabular}

Lacmax (maximum laccases activity), thac,max (time to reach the maximum laccases activity), Permax (maximum total peroxidase activity), tPer,max (time to reach the maximum total peroxidase activity), $\mathbf{M n P}_{\max }$ (maximum manganese peroxidase activity), $\mathbf{t}_{\mathrm{MnP}, \max }$ (time to reach the maximum manganese peroxidase activity), LiP $\max$ (maximum lignin peroxidase activity), $\mathbf{t}_{\mathrm{L} i \mathrm{P}, \max }$ (time to reach the maximum lignin peroxidase activity), $\mathbf{V A O}_{\max }$ (maximum veratryl alcohol oxidase activity), $\mathbf{t}_{\mathbf{v A O} \text {,max }}$ (time to reach the maximum veratryl alcohol oxidase activity), Proteases (maximum proteolytic activity), tprot,max (time to reach maximum protease activity), ND (enzymatic activity not detected).

For all conditions assayed, total soluble protein concentrations (TSP) were similar at the beginning of the experiments, showing an increase after $96 \mathrm{~h}$ and until the end of cultivations. This might be related to biomass autolysis after total substrate consumption, resulting in release of structural and intracellular proteins. It is important to emphasize that the behaviour of total protein kinetics for the $30 \%$ and $80 \%$ experiments was similar (>130 $\mathrm{mg} \mathrm{L}^{-1}$ after $96 \mathrm{~h}$ ), while only the uncontrolled experiment showed lower levels $\left(<70 \mathrm{mg} \mathrm{L}^{-1}\right)$ during incubation.

Overall data obtained during the experiments are shown in Table 2. Except for $\mu_{\mathrm{X}, \mathrm{m}}$ data, all results referring to the enzyme $\left(\mathrm{Y}_{\mathrm{E} / \mathrm{S}}, \mathrm{P}_{\mathrm{E}}, \mathrm{TSP}\right.$ and $\mathrm{SA}_{\mathrm{Lac}}$ - with relation to soluble protein and biomass concentrations) refer to the time at which maximum laccases activity was detected, while data referring to biomass ( $\mathrm{Y}_{\mathrm{X} / \mathrm{s}}$ and $\left.P_{X}\right)$ refer to the time during which maximum biomass concentration was observed. $Y_{E / X}$ establishes the relationship between the maximum laccases activity and maximum biomass concentration, regardless of the time of cultivation.

Generally, results for all parameters referring to laccases activities $\left(Y_{E / S}, P_{E}, T S P\right.$ and $\left.S A_{L a c}\right)$ were higher in the experiment at 30\% DO concentration, during which highest enzymatic activities were detected (Figure 1B). Intermediate and lowest levels were observed in uncontrolled and $80 \%$ experiments, respectively. However, the analysis of parameters related to biomass ( $\mu_{\mathrm{x}, \mathrm{m}}, \mathrm{Y}_{\mathrm{x} / \mathrm{s}}$ and $\left.\mathrm{P}_{\mathrm{x}}\right)$ show that the best results were obtained for the $30 \%$ and $80 \%$ DO experiments, which were also more favourable to microorganism growth (Figure 1B and 1C), while the uncontrolled experiment presented lower levels for all parameters evaluated. 
Table 2. General results of submerged cultivations of Pleurotus sajor-caju PS-2001 in stirred-tank bioreactor under different conditions for dissolved oxygen concentration at $\mathrm{pH}$ controlled between 4.5 and 7.0.

\begin{tabular}{|c|c|c|c|}
\hline \multirow{2}{*}{ Parameter evaluated } & \multicolumn{3}{|c|}{ Dissolved oxygen (per cent minimum of saturation) } \\
\hline & Uncontrolled & $30 \%$ & $80 \%$ \\
\hline $\mathrm{Lac}_{\max }\left(\mathrm{U} \mathrm{mL}^{-1}\right)$ & 17.6 & 26.4 & 6.60 \\
\hline$t_{\text {Lac }}(h)$ & 96 & 96 & 24 \\
\hline$Y_{E / S}\left(U_{q^{-1}}\right)$ & 2624 & 3248 & 668 \\
\hline$P_{E}\left(U \mathbf{m L}^{-1} h^{-1}\right)$ & 0.138 & 0.168 & 0.031 \\
\hline $\operatorname{TSP}\left(\mathrm{mg} \mathrm{L}^{-1}\right)$ & 53 & 65 & 20 \\
\hline $\mathrm{SA}_{\mathrm{Lac}}\left(\mathrm{U} \mathrm{mg}^{-1}\right.$ of protein) & 330 & 406 & 298 \\
\hline $\mathbf{S A}_{\text {Lac }}\left(\mathrm{U} \mathrm{g}^{-1}\right.$ of biomass) & 5752 & 7059 & 6226 \\
\hline$\mu \mathrm{x}, \mathrm{m}\left(\mathrm{h}^{-1}\right)$ & 0.032 & 0.044 & 0.040 \\
\hline$X_{\max }\left(g^{-1}\right)$ & 2.55 & 4.58 & 4.68 \\
\hline$t_{x \max }(h)$ & 72 & 72 & 90 \\
\hline$Y_{x / S}\left(g^{-1}\right)$ & 0.467 & 0.873 & 0.859 \\
\hline$P x\left(g^{-1} h^{-1}\right)$ & 0.032 & 0.060 & 0.048 \\
\hline$Y_{E / X}\left(\mathbf{U}^{-1}\right)$ & 6.90 & 5.76 & 1.41 \\
\hline
\end{tabular}

$\mathbf{L a C}_{\max }$ (maximum laccases activity), $\mathbf{t}_{\mathbf{L a c}}$ (time to reach maximum laccases activity), $\mathbf{Y}_{\mathbf{E} / \mathbf{S}}$ (laccases activity yield from glucose), $\mathbf{P}_{\mathrm{E}}$ (laccases volumetric productivity), TSP (total soluble proteins concentration), SA Lac (laccases specific activity - related to protein and biomass concentrations), $\mu \mathrm{x}, \mathbf{m}$ (maximum specific growth rate), $\mathbf{X}_{\max }$ (maximum biomass concentration), $\mathbf{t}_{\mathbf{x} \max }$ (time to reach the maximum biomass concentration), $\mathbf{Y}_{\mathbf{X} / \mathbf{s}}$ (biomass yield from glucose), $\mathbf{P} \mathbf{x}$ (biomass volumetric productivity), $\mathbf{Y}_{\mathbf{E} / \mathbf{X}}$ (specific yield factor).

\section{Bioreactor cultivations at fixed $\mathrm{pH}$ of 6.5}

For the strain evaluated in this work, studies conducted earlier showed an increase in the synthesis of laccases with the medium $\mathrm{pH}$ controlled at 6.5 (data not shown). Thus, new tests were performed using this $\mathrm{pH}$ value, evaluating the oxygen supply under the conditions in which the best results were observed for $\mathrm{pH}$ between 4.5 and 7.0: uncontrolled DO concentration and DO controlled in minimum levels of 10,30 and $50 \%$.

In Figure 2, the time courses for laccases activities and substrate and biomass concentrations under different conditions tested for oxygen supply are presented. As shown, DO concentrations close to $30 \%$ of saturation provide higher enzyme levels in comparison to thus determined in tests carried out with uncontrolled DO and with minimum levels of 10 and $50 \%$, showing peak of $80 \mathrm{U} \mathrm{mL}^{-1}$ in $66 \mathrm{~h}$ of cultivation (Figure 2C). It was observed a gradual decline in the concentration of glucose in all conditions evaluated, with concomitant increased mycelial biomass. Superior concentrations of biomass were measured at $50 \%$ DO saturation condition, with a peak of $2.8 \mathrm{~g} \mathrm{~L}^{-1}$ in $66 \mathrm{~h}$ of cultivation (Figure 2D). The highest laccases production test was the one who showed the smallest fungal growth (Figure $2 \mathrm{C}$ ). Under uncontrolled DO and with $10 \%$ of saturation (Figure $2 \mathrm{~A}$ and $2 \mathrm{D}$ ), the kinetic behaviours of both substrate consumption and biomass formation were very similar.

In all experiments, the minimum levels established for DO - 10, 30 and $50 \%$ - have been achieved between 24 and $60 \mathrm{~h}$ of cultivation (data not shown). In the test carried out with uncontrolled DO, very low levels of oxygen were detected as early as $48 \mathrm{~h}$, remaining at values near to $0 \%$ from $60 \mathrm{~h}$ until the end of the test, as a result of the fungal metabolism.

In Table 3, the maximum enzymatic activities attained and their respective maximum detection times are presented. Increased levels of laccases and total peroxidase were observed in tests with $30 \%$ DO saturation. For MnP, higher activities occurred with $50 \%$ of saturation in OD. LiP was not detected and VAO were measured only in test with $30 \%$ of DO. The proteolytic activity was less than $2 \mathrm{U} \mathrm{mL}^{-1}$ in all tests. 

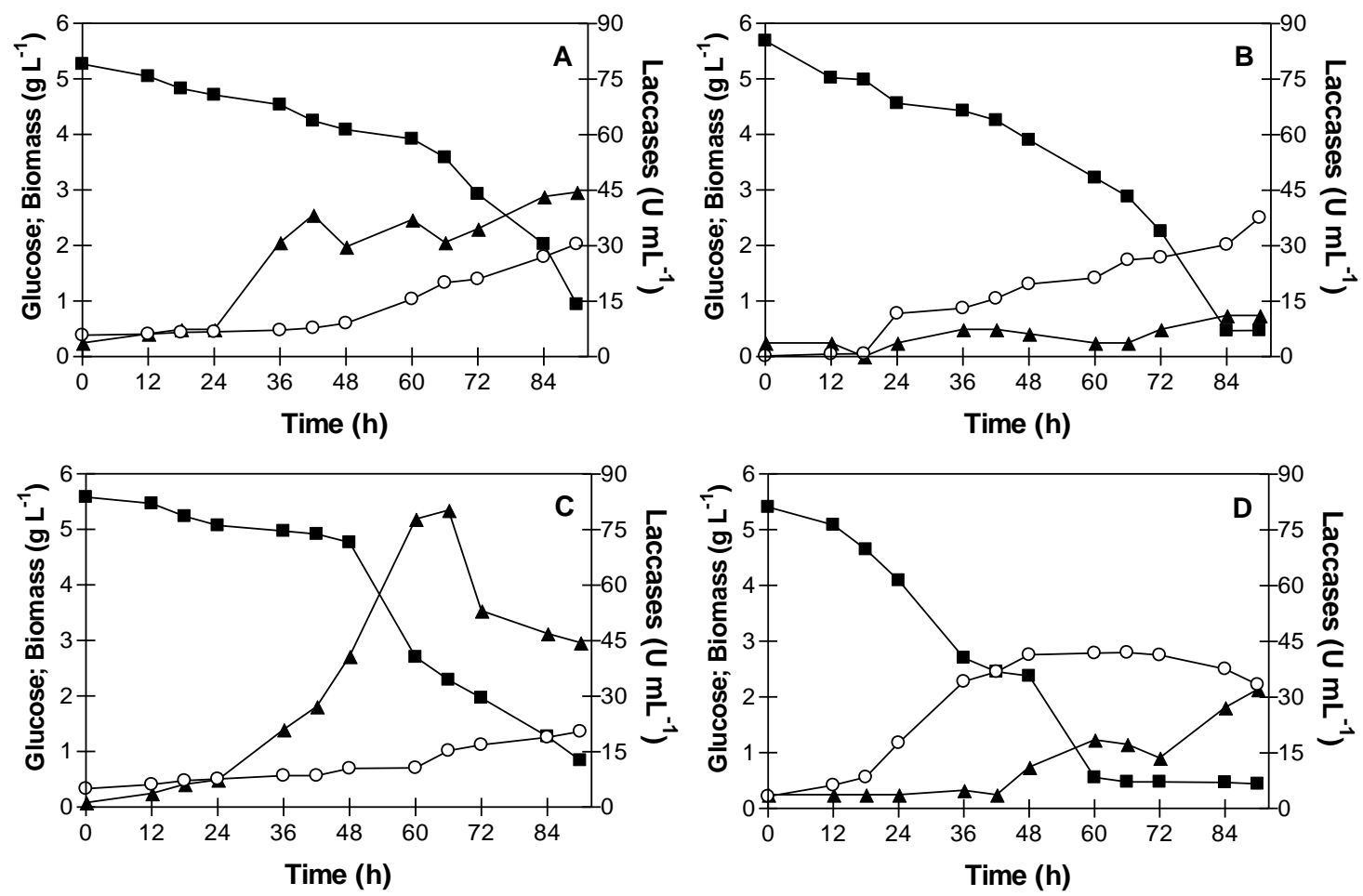

Figure 2. Laccases activity $(\mathbf{\Lambda})$ and glucose ( $\mathbf{m})$ and biomass (o) concentrations during submerged cultivations of Pleurotus sajor-caju PS-2001 in stirred-tank bioreactor under different dissolved oxygen concentration conditions, at fixed $\mathrm{pH}$ of 6.5 . Uncontrolled oxygen concentration (A), $10 \%$ (B), $30 \%$ (C) and $50 \%$ of saturation (D).

Table 3. Maximum activities of phenol-oxidases and proteases observed during submerged cultivations of Pleurotus sajor-caju PS-2001 in stirred-tank bioreactor under different conditions for dissolved oxygen concentration at fixed pH of 6.5 .

\begin{tabular}{|c|c|c|c|c|}
\hline \multirow{2}{*}{ Enzyme activity } & \multicolumn{4}{|c|}{ Dissolved oxygen (per cent minimum of saturation) } \\
\hline & Uncontrolled & $10 \%$ & $30 \%$ & $50 \%$ \\
\hline $\mathrm{Lac}_{\max }\left(\mathrm{U} \mathrm{mL}^{-1}\right)$ & 44.4 & 11.1 & 80.2 & 32.0 \\
\hline$t_{\text {Lac, } \max }(\mathrm{h})$ & 90 & 84 & 66 & 90 \\
\hline $\operatorname{Per}_{\max }\left(\mathrm{U}^{\mathrm{mL}} \mathrm{L}^{-1}\right)$ & 9.87 & 3.70 & 19.7 & 4.94 \\
\hline$t_{\text {Per,max }}(h)$ & 48 & 66 & 72 & 90 \\
\hline $\mathrm{MnP}_{\max }\left(\mathrm{U} \mathrm{mL}^{-1}\right)$ & 2.40 & 1.90 & 0.09 & 3.32 \\
\hline$t_{M n P, \max }(h)$ & 90 & 36 & 48 & 84 \\
\hline $\mathrm{LiP}_{\max }\left(\mathrm{U} \mathrm{mL}^{-1}\right)$ & ND & ND & ND & ND \\
\hline$t_{L i P, \max }(h)$ & --- & --- & --- & --- \\
\hline $\mathrm{VAO}_{\max }\left(\mathrm{U} \mathrm{mL}^{-1}\right)$ & 0.21 & ND & ND & ND \\
\hline$t_{V A O, \max }(\mathrm{h})$ & 48 & --- & --- & --- \\
\hline Proteases & 0.77 & 1.66 & 0.53 & 1.27 \\
\hline$t_{\text {Prot,max }}(h)$ & 0 & 90 & 84 & 24 \\
\hline
\end{tabular}

Lacmax (maximum laccases activity), thac,max (time to reach the maximum laccases activity), Per max (maximum total peroxidase activity), $\mathbf{t}_{\text {Per, } \max }$ (time to reach the maximum total peroxidase activity), $\mathbf{M n}_{\mathbf{n} \text { max }}$ (maximum manganese peroxidase activity), $\mathbf{t}_{\mathbf{M n P}, \mathbf{m a x}}$ (time to reach the maximum manganese peroxidase activity), $\mathbf{L i P}_{\max }$ (maximum lignin peroxidase activity), $\mathbf{t}_{\mathbf{L} i P, \max }$ (time to reach the maximum lignin peroxidase activity), VAO $\max$ (maximum veratryl alcohol oxidase activity), tvao,max (time to reach the maximum veratryl alcohol oxidase activity), Proteases (maximum proteolytic activity), tprot,max (time to reach maximum protease activity), ND (enzymatic activity not detected).

Total soluble protein (TSP) showed maximum levels close to $500 \mathrm{mg} \mathrm{L}^{-1}$ in test performed with uncontrolled dissolved $\mathrm{O}_{2}$. However, in the other conditions evaluated, the values were lower than $350 \mathrm{mg} \mathrm{L}^{-}$ ${ }_{1}^{1}$, showing similar behaviour profiles during the process.

In Table 4, the general results obtained in cultures performed at $\mathrm{pH} 6.5$ are shown. Except for $\mu \mathrm{x,m}$ data, all results referring to the enzyme $\left(\mathrm{Y}_{\mathrm{E} / \mathrm{S}}, \mathrm{P}_{\mathrm{E}}, \mathrm{TSP}\right.$ and $S A_{\mathrm{Lac}}$ - with relation to soluble protein and biomass concentrations) refer to the time at which maximum laccases activity was detected, while data referring to biomass $\left(\mathrm{Y}_{\mathrm{X} / \mathrm{S}}\right.$ and $\mathrm{P}_{\mathrm{X}}$ ) refer to the time during which maximum biomass concentration was observed. $\mathrm{Y}_{\mathrm{E} / \mathrm{X}}$ is the relationship between the maximum laccases activity and maximum biomass concentration. 
Table 4. General results of submerged cultivations of Pleurotus sajor-caju PS-2001 in stirred-tank bioreactor under different conditions for dissolved oxygen concentration at $\mathrm{pH} 6.5$.

\begin{tabular}{|c|c|c|c|c|}
\hline \multirow{2}{*}{ Parameter evaluated } & \multicolumn{4}{|c|}{ Dissolved oxygen (per cent minimum of saturation) } \\
\hline & Uncontrolled & $10 \%$ & $30 \%$ & $50 \%$ \\
\hline $\mathrm{Lac}_{\max }\left(\mathrm{U} \mathrm{mL}^{-1}\right)$ & 44.4 & 11.1 & 80.2 & 32.0 \\
\hline$t_{\text {Lac }}(h)$ & 90 & 84 & 66 & 90 \\
\hline$Y_{E / S}\left(U_{q^{-1}}\right)$ & 9417 & 1419 & 24029 & 5723 \\
\hline$P_{E}\left(U \mathbf{m L}^{-1} h^{-1}\right)$ & 0.453 & 0.088 & 1.197 & 0.316 \\
\hline $\mathrm{TSP}\left(\mathrm{mg} \mathrm{L}^{-1}\right)$ & 459 & 284 & 81 & 266 \\
\hline $\mathrm{SA}_{\mathrm{Lac}}\left(\mathrm{U} \mathrm{mq}^{-1}\right.$ of protein) & 97 & 39 & 986 & 121 \\
\hline$S A_{\text {Lac }}\left(\mathrm{U} \mathrm{g}^{-1}\right.$ of biomass) & 21894 & 5500 & 78673 & 14459 \\
\hline$\mu_{\mathrm{X}, \mathrm{m}}\left(\mathrm{h}^{-1}\right)$ & 0.034 & 0.028 & 0.022 & 0.038 \\
\hline$X_{\max }\left(g^{-1}\right)$ & 2.03 & 2.50 & 1.36 & 2.80 \\
\hline$t_{X \max }(h)$ & 90 & 90 & 90 & 66 \\
\hline$Y_{x / s}\left(g^{-1}\right)$ & 0.379 & 0.409 & 0.285 & 0.524 \\
\hline $\operatorname{Px}\left(q^{-1} h^{-1}\right)$ & 0.018 & 0.024 & 0.011 & 0.039 \\
\hline$Y_{E / X}\left(U g^{-1}\right)$ & 21.9 & 4.44 & 59.0 & 11.4 \\
\hline
\end{tabular}

$\mathbf{L} \mathbf{C C}_{\max }$ (maximum laccases activity), $\mathbf{t}_{\mathbf{L a c}}$ (time to reach maximum laccases activity), $\mathbf{Y}_{\mathbf{E} / \mathbf{S}}$ (laccases activity yield from glucose), $\mathbf{P}_{\mathrm{E}}$ (laccases volumetric productivity), TSP (total soluble proteins concentration), SA Lac (laccases specific activity - related to protein and biomass concentrations), $\mu \mathbf{x}, \mathbf{m}$ (maximum specific growth rate), $\mathbf{X}_{\max }$ (maximum biomass concentration), $\mathbf{t}_{\mathbf{x} \max }$ (time to reach the maximum biomass concentration), $\mathbf{Y}_{\mathbf{X} / \mathbf{s}}$ (biomass yield from glucose), $\mathbf{P} \mathbf{x}$ (biomass volumetric productivity), $\mathbf{Y}_{\mathbf{E} / \mathbf{X}}$ (specific yield factor).

For all parameters related to the synthesis of laccases (Table 4), superior results were observed in the test conducted on minimum values of $30 \%$ DO saturation $\left(Y_{E / S}, P_{E}, S A_{L a c}\right.$ and $\left.Y_{E / X}\right)$, quite higher than those found in the further conditions, highlighting the enzymatic productivity $\left(P_{E}\right)$ and specific yield factor $\left(Y_{E / X}\right)$. In this test, also smaller biomass concentration was measured, showing that there is no proportional relationship between growth and synthesis of laccases, which also occurred with the concentration of total soluble proteins. For the biomass parameters, superior results were obtained in the test with higher growth $(50 \%$ DO saturation).

\section{DISCUSSION}

Aerobic processes require a non-limiting amount of dissolved oxygen for microbial respiration. Oxygen supply directly affects biomass and is a crucial parameter for ensuring the adequate growth, cellular maintenance and production of metabolites. However, this gas is poorly soluble in aqueous media, so supplying oxygen to a culture is a complex task that is also affected by high levels of soluble nutrients [43].

Submerged fermentation of higher fungi is characterized by an increase in broth viscosity with time, either as a consequence of increased cell concentration, changes in microbial morphology, or because of the accumulation of extracellular products that alter the rheological characteristics of fermentation broth. After these changes, there will be several problems that should be considered and solved, especially with respect to oxygen supply. Oxygen affects cell growth, cellular morphology, nutrients uptake, and metabolite biosynthesis [32].

Oxygen, as a restricting nutrient, might cause severe alterations in the culture medium, positively or negatively interfering not only in microorganism growth but also in obtaining products of interests. The experiments of the present work show that high DO concentration in bioreactor does not favour laccases production, and its restriction, even if temporary, was significantly more beneficial to enzyme activity (Figure 1 and 2). Therefore, it might be suggested that $P$. sajor-caju PS-2001, when under stress conditions due to lack or restriction of oxygen, tends to increase laccases production, in contrast to a condition of high $\mathrm{O}_{2}$ saturation, which negatively influences enzyme production.

In general, according to the results obtained, it was found that the tests conducted at $\mathrm{pH}$ between 4.5 and 7.0 favoured fungal growth, while tests carried out at fixed $\mathrm{pH}$ of 6.5 resulted in higher enzymatic levels However, among all the DO concentrations conditions tested, keeping DO at a minimum of $30 \%$ of saturation led to the highest laccases titles, regardless of the $\mathrm{pH}$ used. Shu and coauthors [44] observed that $\mathrm{pH}$ values of 4.0 and 5.0 are preferable for the cultivation of Agaricus blazei in stirred-tank bioreactor. For the ligninolytic fungus Trametes versicolor, Borràs and coauthors [45] reported that 4.5 is the ideal pH for growth. According to Thurston [7], when the fungus is grown on a medium whose $\mathrm{pH}$ is inadequately high for growth (around $\mathrm{pH}$ 5.0), laccases production is favoured.

Laccases are the main enzymes produced by P. sajor-caju PS-2001, although considerable levels of peroxidases have also been detected. However, MnP, LiP and VAO have shown low activity under any condition tested, as already noted in previous studies [28]. In experiments performed with the strain $\mathrm{Pl}-27$ of 
P. sajor-caju, Fu and coauthors [46] have shown the fungus that produces MnP and laccases, but do not produce LiP in a medium containing glucose as substrate. The proteolytic activities showed no negative interference on the synthesis of laccases and the other phenol-oxidases quantified, showing relatively low levels in all cultivation (Tables 1 and 3).

The evaluations parameters for laccases and biomass presented in Tables 2 and 4 help to provide an understanding of the behaviour of the fungus under the conditions evaluated. Among these parameters, it is important to highlight the specific yield factor $\left(Y_{E / X}\right)$, which proves that a high mycelial growth is not directly related to an increase in the synthesis of laccases, as verified, for example, in the cultivation at $30 \%$ of DO saturation and $\mathrm{pH} 6.5$ (Table 4).

The maximum specific growth rates $(\mu \mathrm{x}, \mathrm{m})$ in the range 0,022 to $0,044 \mathrm{~h}^{-1}$ (Tables 2 and 4 ) are in agreement with values found for $P$. sajor-caju PS-2001 in previous studies conducted in stirred-tank reactor (STR). In those cultivation, carried out in a similar medium, with sucrose as a carbon source and gallic acid as enzyme inducer, replacing glucose and benzoic acid used in the present work, biomass concentration reached $5.2 \mathrm{~g} \mathrm{~L}^{-1}$, which is greater than those observed in this work comparing all the conditions tested. However, the maximum laccases activity was only $40 \mathrm{U} \mathrm{mL}^{-1}$, half the value obtained with growth conditions at $30 \% \mathrm{DO}$ saturation and $\mathrm{pH} 6.5$, which was after $80 \mathrm{U} \mathrm{mL}^{-1}$ (Table 3) [28].

As reported in literature, culture conditions such as impellers speed, airflow rate, $\mathrm{pH}$, temperature, and medium composition directly influence fungal biomass growth and morphology as well as enzymatic activities $[22,47,48]$. In this study, initial aeration and agitation conditions were relatively gentle to prevent mycelial shearing, a damage frequently seen when filamentous fungi are cultivated in stirred-tank bioreactors. Such a situation was reported by Venkatadri and Irvine [49] for the cultivation of Phanerochaete chrysosporium, whose data showed a low production of ligninolytic enzymes in bioreactor, correlated with high impellers speed and consequent mycelial disruption. The negative effect caused by agitation (mechanical stress) on the production of fungal peroxidases and laccases was also observed in tests with Panus tigrinus in stirredtank bioreactor [50]. In addition, agitation intensity influences not only laccases activities in bioreactor but also biocatalyst stability [51].

Data from bioreactor experiments show that the highest DO levels used in this work -30 and $80 \%$ of saturation - led to increasing fungal growth at $\mathrm{pH}$ between 4.5 and 7.0. Such results disagree with those obtained by Lee and coauthors [52] that reported higher concentration of mycelial biomass of Grifola frondosa under lower oxygenation of the cultivation medium. For Antrodia cinnamomea, it was observed that a high oxygen supply favours mycelial growth but the production of bioactive metabolites such as enzymes and extracellular polysaccharides [25] is inhibited. Therefore, these results suggest that there might be great variations in growth and metabolites production for different fungal species depending on the oxygen supply.

Results shown in Figures 1 and 2 suggest that laccases production by P. sajor-caju PS-2001 follows an associated kinetics model, where enzymatic synthesis occurs at the same time as microorganism growth, substrate consumption and decrease in $\mathrm{DO}$ and $\mathrm{pH}$ levels during primary metabolism [53]. However, studies with Volvariella volvacea report that enzymatic synthesis of this white-rot fungus is associated with secondary metabolism and it is positively regulated by the addition of up to $200 \mu \mathrm{mol} \mathrm{L}^{-1} \mathrm{CuSO}_{4}$ and several aromatic compounds [54].

Lai and coauthors [55] studied the effects of dissolved oxygen concentrations between 10 and $40 \%$ of saturation on the cultivation of Aspergillus terreus for obtaining secondary metabolites. According to these authors, increasing biomass concentrations were attained at DO of 30 and $40 \%$. However, the high shear stress caused by the impeller speed necessary to maintain $40 \%$ of DO caused partial destruction of pellets and considerable reduction of production in comparison to the experiment in which $30 \%$ of DO was maintained. For the cultivation of Aspergillus niger, Li and coauthors [56] found that there was no inhibition of growth or nutrient consumption by the fungus, even at DO concentrations over $50 \%$ of saturation.

Stirred tank bioreactors have two particular problems that can be pointed out: the shearing of mycelium and the energy required to maintain the homogeneity of the medium. STR is normally used for enzyme production; however, the high-shear area due to the impellers, especially when a more intense agitation condition is required for achieving an adequate oxygen transfer to the liquid phase, can damage the microorganisms [57]. In spite of this, STR provides the attainment of superior results in terms of enzyme production when compared to bioreactors that allow a less shear-stressing environment, as observed by Fontana and coauthors [33] in the cultivation of Aspergillus oryzae for producing polygalacturonases in both mechanically stirred and airlift bioreactors. Meneghel and coauthors [58] evaluated cultures grown with limiting and non-limiting oxygen supplies of $A$. oryzae in STR for pectinases production, suggesting that the use of a growth-limiting medium can provide an effective oxygen supply to the microorganisms and excessively high impeller speeds that could damage the fungal hyphae. 
Even today, STR are the most widely used cultivation systems with large applicability in industry and in laboratory scale, due to their great operational flexibility, being used in a large variety of bioprocesses such as the degradation of toxic compounds and the production of enzymes, biomass, polysaccharides and other microbial metabolites from different organisms [13,14,16,25,28,32,33,43,49-51,55-58].

\section{CONCLUSION}

In conclusion, the results of this work make evident that dissolved oxygen concentration is a critical factor in the culture of $P$. sajor-caju PS-2001, with important effects not only on laccases production but also on fungal growth. Thus, it should be carefully assessed and controlled to achieve the best performance of the process. Data show that stress conditions by lack or restriction of oxygen supply might have positive effects on laccases production, in contrast to high availability of $\mathrm{O}_{2}$, which tends to negatively influence enzymatic production. Regardless of the $\mathrm{pH}$ used, the synthesis of laccases is favoured by maintaining the concentration of dissolved oxygen close to $30 \%$ of saturation, whereas superior DO levels favour fungal growth.

Funding: This research received no external funding.

Conflicts of Interest: The authors declare no conflict of interest.

Acknowledgments: This work was supported by grants from the Universidade de Caxias do Sul (UCS) and Conselho Nacional de Desenvolvimento Científico e Tecnológico (CNPq, Brazil). F. Bettin was supported by post-doctoral fellowships from the Fundação de Amparo à Pesquisa do Estado do Rio Grande do Sul (FAPERGS, Brazil) and the Coordenadoria de Aperfeiçoamento de Pessoal de Nível Superior (CAPES, Brazil).

\section{REFERENCES}

1. Cohen R, Persky L, Hadar Y. Biotechnological applications and potential of wood-degrading mushrooms of the genus Pleurotus. Appl Microbiol Biotechnol. 2002 Apr; 58(5):582-94.

2. Stajic M, Persky L, Friesem D, Hadar Y, Wasser SP, Nevo E, Vukojevic J. Effect of different carbon and nitrogen sources on laccase and peroxidases production by selected Pleutorus species. Enzyme Microb Technol. 2006 Feb; 38:65-73.

3. Gill PK, Arora DS. Effect of culture conditions on manganese peroxidase production and activity by some white rot fungi. J Ind Microbiol Biotechnol. 2003 Jan; 30(1):28-33.

4. Elisashvili V, Kachlishvili E. Physiological regulation of laccase and manganese peroxidase production by white-rot Basidiomycetes. J Biotechnol. 2009 Oct; 144(1):37-42.

5. Pandey A, Soccol CR, Mitchell D. New developments in solid state fermentation: I-bioprocesses and products. Process Biochem. 2000 Jul; 35(10):1153-69.

6. Barr DP, Aust SD. Mechanism white rot fungi use to degrade pollutants. Environ Sci Technol. 1994 Feb; 28(2):7887.

7. Thurston CF. The structure and function of fungal laccases. Microbiology. 1994 Jan; 140(1):19-26.

8. Durán N, Esposito E. Potential applications of oxidative enzymes and phenoloxidase-like compounds in wastewater and soil treatment: a review. Appl Catal B Environ. 2000 Oct; 28(2):83-99.

9. Jolivalt C, Madzak C, Brault A, Caminade E, Malosse C, Mougin C. Expression of laccase Illb from the white-rot fungus Trametes versicolor in the yeast Yarrowia lipolytica for environmental applications. Appl Microbiol Biotechnol. 2005 Jan; 66(4):450-6.

10.Asif MB, Hai FI, Singh L, Price WE, Nghiem LD. Degradation of pharmaceuticals and personal care products by white-rot fungi: a critical review. Curr Pollution Rep. 2017 Jan; 3(2):88-103.

11.Alneyadi AH, Rauf MA, Ashraf SS. Oxidoreductases for the remediation of organic pollutants in water: a critical review. Crit Rev Biotechnol. 2018 Nov; 38(7):971-88.

12.Breen A, Singleton FL. Fungi in lignocellulose breakdown and biopulping. Curr Opin Biotechnol. 1999 Jun; 10(3):2528.

13.Blánquez $P$, Caminal G, Sarrà M, Vicent MT, Gabarrell X. Olive oil mill waste waters decoloration and detoxification in a bioreactor by the white rot fungus Phanerochaete flavido-alba. Biotechnol Prog. 2002 May-Jun; 18(3):660-2.

14. Bettin F, Cousseau F, Martins K, Boff NA, Zaccaria S, Silveira MM, Dillon AJP. Phenol removal by laccases and other phenol oxidases of Pleurotus sajor-caju PS-2001 in submerged cultivations and aqueous mixtures. J Environ Manage. 2019 Apr; 236:581-90.

15.Bettin F, Cousseau F, Martins K, Zaccaria S, Girardi V, Silveira MM, Dillon AJP. Effects of pH, temperature and agitation on the decolourisation of dyes by laccase-containing enzyme preparation from Pleurotus sajor-caju. Braz Arch Biol Technol. 2019 Jun; 62:e19180338.

16. Cantele C, Fontana RC, Mezzomo AG, Rosa LO, Poleto L, Camassola M, Dillon AJP. Production, characterization and dye decolorization ability of a high level laccase from Marasmiellus palmivorus. Biocatal Agric Biotechnol. 2017 Oct; $12: 15-22$.

17.Dhawan S, Lal R, Hanspal M, Kuhad RC. Effect of antibiotics on growth and laccase production from Cyathus bulleri and Pycnoporus cinnabarinus. Bioresour Technol. 2005 Aug; 96(12):1415-8. 
18.Couto SR, Herrera JLT. Industrial and biotechnological applications of laccases: a review. Biotechnol Adv. 2006 Sep-Oct; 24(5):500-13.

19. Antonopoulou I, Varriale S, Topakas E, Rova U, Christakopoulos P, Faraco V. Enzymatic synthesis of bioactive compounds with high potential for cosmeceutical application. Appl Microbiol Biotechnol. 2016 Aug; 100(15):651943.

20.Agrawal K, Chaturvedi V, Verma P. Fungal laccase discovered but yet undiscovered. Bioresour Bioprocess. 2018 Nov; 5:4-15.

21.Guillén-Navarro GK, Márquez-Rocha FL, Sanchez-Vázquez JE. Producción de biomasa y enzimas ligninolíticas por Pleurotus ostreatus en cultivo submergido. Rev Iberoam Micol. 1998 Jan; 15:302-6.

22.Márquez-Rocha FJ, Guillén NGK, Sánchez VJE, Vázquez-Duhalt R. Growth characteristics of Pleurotus ostreatus in bioreactors. Biotechnol Tech. 1999 Jan; 13:29-32.

23.Wu JZ, Cheung PCK, Wong KH, Huang NL. Studies on submerged fermentation of Pleurotus tuber-regium (Fr.) Singer. Part 1: physical and chemical factors affecting the rate of mycelial growth and bioconversion efficiency. Food Chem. 2003 Jun; 81(3):389-93.

24.Confortin FG, Marchetto R, Bettin F, Camassola M, Salvador M, Dillon AJP. Production of Pleurotus sajor-caju strain PS-2001 biomass in submerged culture. J Ind Microbiol Biotechnol. 2008 Oct; 35(10):1149-55.

25. Shih IL, Pan K, Hsieh C. Influence of nutritional components and oxygen supply on the mycelial growth and bioactive metabolites production in submerged culture of Antrodia cinnamomea. Process Biochem. 2006 May; 41(5):1129-35.

26. Mikiashvili N, Wasser SP, Nevo E, Elisashvili V. Effects of carbon and nitrogen sources on Pleurotus ostreatus ligninolytic enzyme activity. World J Microbiol Biotechnol. 2006 Feb; 22:999-1002.

27.Bettin F, Montanari Q, Calloni R, Gaio TA, Silveira MM, Dillon AJP. Production of laccases in submerged process by Pleurotus sajor-caju PS-2001 in relation to carbon and organic nitrogen sources, antifoams and Tween 80 . J Ind Microbiol Biotechnol. 2009 Jan; 36(1):1-9.

28. Bettin F, Rosa LO, Montanari Q, Calloni R, Gaio TA, Malvessi E, Silveira MM, Dillon AJP. Growth, kinetics, production, and characterization of extracellular laccases from Pleurotus sajor-caju PS-2001. Process Biochem. 2011 Mar; 46(3):758-64.

29.Bettin F, Montanari Q, Calloni R, Gaio TA, Silveira MM, Dillon AJP. Additive effects of $\mathrm{CuSO}_{4}$ and aromatic compounds on laccase production by Pleurotus sajor-caju PS-2001 using sucrose as a carbon source. Braz J Chem Eng. 2014 Apr-Jun; 31(2):335-46.

30.Gouveia ER, Hokka CO, Badino Jr. AC. The effects of geometry and operational conditions on gas holdup, liquid circulation and mass transfer in an airlift reactor. Braz J Chem Eng. 2003 Out-Dez; 20(4):363-74.

31.Kim SW, Hwang HJ, Xu CP, Choi JW, Yun JW. Effect of aeration and agitation on the production of mycelia biomass and exopolysaccharides in an enthomopathogenic fungus Paecilomyces sinclairii. Lett Appl Microbiol. 2003 May; 36(5):321-6.

32. Tang YJ, Zhong JJ. Role of oxygen supply in submerged fermentation of Ganoderma lucidum for production of Ganoderma polysaccharide and ganoderic acid. Enzyme Microb Technol. 2003 Mar; 32(3-4):478-84.

33.Fontana RC, Silveira MM. Production of polygalacturonase by Aspergillus oryzae in stirred tank and internal- and external-loop airlift reactors. Bioresour Technol. 2012 Nov; 123:157-63.

34.Sobotka M, Prokop A, Dunn II, Einsele A. Review of methods for the measurement of oxygen transfer in microbial systems. In: Annual Reports on Fermentation Process. London: Academic Press; 1982 p.127-210.

35. Wolfenden BS, Willson RL. Radical-cations as reference chromogens in the kinetic studies of one-electron transfer reactions: pulse radiolysis studies of 2,2'-azinobis-(3-ethylbenzthiazoline-6-sulphonate). J Chem Soc Perkin Trans II. 1982 Jan; 2(7):805-12.

36. Heinzkill M, Bech L, Halkier T, Schneider P, Anke T. Characterization of laccases and peroxidases from wood-rotting fungi (Family Coprinaceae). Appl Environ Microbiol. 1998 May; 64(5):1601-6.

37. Kuwahara M, Glenn JK, Morgan MA, Gold MH. Separation and characterization of two extracellular $\mathrm{H}_{2} \mathrm{O}_{2}$-dependent oxidases from ligninolytic cultures of Phanerochaete chrysosporium. FEBS Lett. 1984 Apr; 169(2):247-50.

38. Bourbonnais R, Paice MG. Veratryl alchool oxidases from the lignin-degrading basidiomycete Pleurotus sajor-caju. Biochem J. 1988 Oct; 255(2):445-50.

39.Tien M, Kirk TK. Lignin-degrading enzyme from Phanerochaete chrysosporium: purification, characterization, and catalytic properties of a unique $\mathrm{H}_{2} \mathrm{O}_{2}$-requiring oxygenase. Proc Natl Acad Sci USA. 1984 Apr; 81(8):2280-4.

40.Sarath G, Motte RS, Wagner FW. Protease assay methods. In: Beynon RJ, Bond JS. Proteolytic enzymes: a pratical approach. Oxford: IRL Press; 1989 p.25-55.

41. Miller GL. Use of dinitrosalicilic acid reagent for determination of reducing sugar. Anal Chem. 1959 Mar; 31(3):4268.

42.Bradford MM. A rapid and sensitive method for the quantification of microgram quantities of protein utilizing the principle of protein-dye binding. Anal Biochem. 1976 May; 72(1-2):248-54.

43. Reginatto C, Rossi C, Miglioranza BG, Santos M, Meneghel L, Silveira MM, Malvessi E. Pectinase production by Aspergillus niger LB-02-SF is influenced by the culture medium composition and the addition of the enzyme inducer after biomass growth. Process Biochem. 2017 Jul; 58:1-8.

44. Shu $\mathrm{CH}$, Lin KJ, Wen BJ. Effects of culture pH on the production of bioactive polysaccharides by Agaricus blazei in batch cultures. J Chem Technol Biotechnol. 2004 Jul; 79(9):998-1002. 
45.Borràs E, Blánquez $\mathrm{P}$, Sarrà M, Caminal G, Vincent $\mathrm{T}$. Trametes versicolor pellets production: low-cost medium and scale-up. Biochem Eng J. 2008 Oct; 42(1):61-6.

46. Fu SY, Yu HS, Buswell JA. Effect of a nutrient nitrogen and manganese on manganese peroxidase and laccase production by Pleurotus sajor-caju. FEMS Microbiol Lett. 1997 Feb; 147(1):133-7.

47. Bermek H, Gülseren I, Li K, Jung H, Tamerler C. The effect of fungal morphology on ligninolytic enzyme production by a recently isolated wood-degrading fungus Trichophyton rubrum LSK-27. World J Microbiol Biotechnol. 2004 Jun; 20:345-9.

48. Máximo C, Lageiro M, Duarte A, Reis A, Costa-Ferreira M. Different bioreactor configurations for the decolourisation of the azo dye Reactive Black 5 by Geotrichum sp. CCMI 1019. Biocatal Biotransform.2004 Jul; 22(5-6):307-13.

49.Venkatadri R, Irvine RL. Effect of agitation on ligninase activity and ligninase production by Phanerochaete chrysosporium. Appl Environ Microbiol. 1990 Sep; 56(9):2684-91.

50.Fenice M, Sermanni GG, Federici F, D'Annibale A. Submerged and solid-state production of laccase and Mnperoxidase by Panus tigrinus on olive mill wastewater-based media. J Biotechnol. 2003 Jan; 100(1):77-85.

51. Cabana H, Jones JP, Agathos SN. Utilization of cross-linked laccase aggregates in a perfusion basket reactor for the continuous elimination of endocrine-disrupting chemicals. Biotechnol Bioeng. 2009 Apr; 102(6):1582-92.

52.Lee BC, Bae JT, Pyo HB, Choe TB, Kim SW, Hwang HJ, Yun JW. Submerged culture conditions for the production of mycelial biomass and exopolysaccharides by the edible basidiomycete Grifola frondosa. Enzyme Microb Technol. 2004 Oct; 35(5):369-76.

53.Gaden EL. Fermentation process kinetics. J Biochem Microbiol Technol Eng. 1959 Dec; 1(4):413-9.

54.Chen S, Ma D, Ge W, Buswell JA. Induction of laccase activity in the edible straw mushroom, Volvariella volvacea. FEMS Microbiol Lett. 2003 Jan; 218(1):143-8.

55.Lai LT, Tsai TH, Wang TC, Cheng TY. The influence of culturing environments on lovastatin production by Aspergillus terreus in submerged cultures. Enzyme Microb Technol. 2005 Apr; 36(5-6):737-48.

56. Li Q, Harvey LM, McNeil B. Oxygen enrichment effects on protein oxidation, proteolytic activity and the energy status of submerged batch cultures of Aspergillus niger B1-D. Process Biochem. 2008 Mar; 43(3):238-43.

57. Ritter CET, Fontana RC, Camassola M, Silveira MM, Dillon AJP. The influence of sorbitol on the production of cellulases and xylanases in an airlift bioreactor. Bioresour Technol. 2013 Nov; 148:86-90.

58. Meneghel L, Reis GP, Reginatto C, Malvessi E, Silveira MM. Assessment of pectinase production by Aspergillus oryzae in growth-limiting liquid medium under limited and non-limited oxygen supply. Process Biochem. 2014 Nov; 49(11):1800-7.

(C) 2020 by the authors. Submitted for possible open access publication under the terms and conditions of the Creative Commons Attribution (CC BY NC) license (https://creativecommons.org/licenses/by-nc/4.0/). 